\title{
DEVELOPMENT AND PRESENT STATE OF CLOSE-TO-NATURE SILVICULTURE
}

\author{
JIŘÍ REMEŠ \\ Department of Silviculture, Faculty of Forestry and Wood Sciences, Czech University of \\ Life Sciences Prague, Kamýcká 129, 16500 Praha 6-Suchdol, e-mail: remes@fld.czu.cz.
}

Received: $24^{\text {th }}$ October 2018, Accepted: $20^{\text {th }}$ November 2018

\begin{abstract}
Close to nature silviculture is an alternative to a forest management system based on the clear cutting regeneration and cultivation of even-aged coniferous monocultures. The history of close to nature silviculture dates back to the second half of the 19th century, when the first attempts were made in Central Europe for more sophisticated silvicultural practices based on natural small-scale regeneration and management of mixed stands. These activities also affected the Czech lands, where the ideas of close to nature silviculture were successfully developed by the end of the 1960s. For the next twenty years, however, under the influence of central planning, forest management has been inclined towards large-scale clear cutting system. The renaissance of close to nature forest management took place only after 1989. At present, close to nature silviculture being established not only in Central Europe, but also more and more in the boreal part of Europe as well as in North America. Currently, there is a discussion about suitability of close-to-nature silviculture for adapting temperate forests to climate change.
\end{abstract}

Keywords: close to nature silviculture, forest management, stand structure, uneven-aged stands, mixed stands, climate change, adaptability

\section{INTRODUCTION}

Close-to-nature silviculture (CNS) has progressively established itself as an alternative to the forest management system based on clear cutting and management of even-aged coniferous monocultures (O'Hara, 2016), which was implemented in Central Europe from the mid 18th century. It must be noted that the design and wide application of this system, based ideologically on the model concept of so-called normal forest, has been provoked by the very unfavourable condition of forests caused by extensive exploitation of natural forest ecosystems as a consequence of development of human society since the early Middle Ages. This rational management has brought numerous indubitable positive effects, including primarily assurance of sufficient quantities of high-quality timber, thus averting a crisis of deficiency of ever more demanded raw material, halting of deforestation, and an increase in timber stock in forests constantly since then (Remeš \& Kozel, 2006). The continuity of production in this system was ensured based on age and area. The sophisticated temporal and spatial arrangement of age categories of spruce forest was, at the time, a modern rational method of management, most appropriate to the peaking industrial and agricultural revolution. The system is still functional and would be economically efficient as well, if it 
were not undermined by natural calamities and if its repetition did not jeopardize the production base of the forest (Tesař et al., 2004). Acidic and impoverished forest soil with unstable forest stands, largely monocultures, increasingly affected by all kinds of calamities, were in fact the main reasons for the earliest attempts to change the forest management methods (Poleno, 1996).

\section{HISTORY AND DEVELOPMENT OF CNS}

Bernhardt was the first prominent forester to oppose the ne consequences of the net land yield theory; he pointed out the errors of the current management method of management of age class forests and recommended a transition to selective forest. However, Gayer (1880-1895) provoked more response some time later due to his practical results; he declared the requirement "Back to Nature", and in this spirit he formulated principles of biologically appropriate forest management, natural forest regeneration by small-scale cluster (shelterwood) logging, cultivation of mixed-age mixed-species stands of site-appropriate trees, and justified these principles and implemented them in practice. His concept gained a favourable response not only in Germany but notably in Switzerland, where Biolley, for example, supported his ideas. Gayer's principles were also successfully implemented in the Czech territory, particularly by Sigmond, later silviculture professor at CTU Prague, and Konias of Opočno manor farm (Poleno, 1996).

Möller (1921; 1922), professor at the Eberswalde Forest Academy, elicited a very strong impetus for a departure from clear-cutting forestry with his idea of Dauerwald - permanent forest, a new concept of viable natural forest as an organism. This constantly productive forest was meant to be a variation on selective forests in the pine stands of the North German Lowland. Based on Möller's ideas, Krutzsch defined the main principles of forest management, which he first titled "nature-pursuing forest management" together with Weck (1934) and then used the term "natural managed forest" and "natural forest management" due to unclarity of Möller's definition of Dauerwald. However, he professed Möller's idea of continuously productive forest, according to which the forest is an organism with its own living principles and developmental tendencies, and he recognised the selective forestry principles. The school of forestry known as "stand volume stock management" was formulated theoretically by Rubner $(1931 ; 1936)$ and consisted in constant application of selection in forest stands (regardless of their age). He emphasised the individuality of each tree, i.e., differences in quality and productivity, and this individuality was the basis for constant selection. This was a fundamental departure from clear-cutting management methods and a transition mostly to selection of individual trees even in regeneration logging. These efforts were reflected in the Czech Republic's territory as well, particularly the school of stand volume stock management. It was the case of both the South Bohemian Schwarzenberg forest property and Chomutov municipal forests (Heger, 1930, 1953; Heger \& Schönbach, 1955).

Besides the terms close to nature silviculture (Haveraaen, 1995, close-to-nature forestry Mlinšek, 1996), other names are in use, such as ecologically oriented silviculture (Frivold, 1992), ecologically sound silviculture (Poleno, 1993; 1994), diversity oriented silviculture (Lähde et al., 1999), and nature oriented silviculture (Koch \& Skovsgaard, 1999). The Czech lands have also adopted the term formulated by Prof. Thomasius as ecologically justified silviculture (Ökogerechte Forstwirtschaft). The English term free-style silviculture has come into use recently. Most alternative approaches apply terms such as holistic forestry, ecoforestry, common sense forestry, continuous cover forestry, ecosystem management (O’Hara, 2014). 
Although the ideas of close-to-nature forestry originated in the broader Central Europe, they soon propagated to other parts of Europe and the world. It is also the case of the boreal parts of Europe, where the questioning of the large developmental cycle concept, i.e., area-wide disintegration of forest stands due to disturbance factors (Steijlen \& Zacrisson, 1986; Oliver \& Larson, 1996) has led to promotion of no-clearing regeneration methods. Based on research into the structure of natural forests and their natural development dynamics, some authors have concluded that forests in the boreal zone are composed primarily of mixed stands of different height and diameter (uneven-sized mixed stands Lähde et al., 1999; Hytteborn et al., 1987; Bonan \& Shugart, 1989). These findings have led to the effort for greater application of alternative forms of silviculture focused on greatest stand diversity in the boreal zone (diversity-oriented silviculture). The first cultivation concept is cultivation of fully diversified stands (regularly all-sized stands), which are characterised by a diameter structure typical of selectively managed forests of Central Europe. This silviculture form recommends both single tree selection and group selection, which should be applied in stands with a more prominent presence of light-demanding trees (pines, birches and aspens). The basic model for the structure of stands managed in this way is the decreasing frequency of trees in thickness categories with a recommended q factor of 1.6. It is recommended to gradually rebuilt other types of forest stands, also known as structurally (dimensionally) differentiated (moundy uneven-sized stands, storeyed stands) into fully diversified stands (regularly all-sized stands). There are also procedures for achieving greater structural diversification from originally highly homogenous stands (even-sized stands) (Lähde et al., 1999).

Similarly to Europe, North America has seen periods of increasing interest in close-to-nature management methods as well as decreasing popularity of these management schools in forestry. Three main reasons are given for the cultivation of uneven-aged stands in North America (O'Hara, 2002):

- economic effectiveness of logging - maximised net revenues are provided by economic selective logging, focusing on the largest trees only;

- closer-to-nature stand structure - management of uneven-aged stands is the most natural of all management methods;

- influence of European forestry (selective management tradition) - many of the earliest foresters in North America were Europeans by origin or at least studied in Europe.

The development and applicability of close-to-nature silviculture are different in different regions of North America due to its large area. For example, the first attempt to introduce selective management principles in the coastal Pacific area of forest stands with a significant presence of Douglas fir was registered in the 1930s. The northeastern areas of the USA and eastern Canada comprise a forestry-specific region with a significant presence of mixed deciduous forest. This forest is unique for its great diversity and presence of shade-loving and economically valuable tree species. That offers much greater opportunities for cultivation of uneven-aged stands similar to those in Europe, i.e., with relatively short rotation periods and with rich natural regeneration. An example of successful cultivation of uneven-aged stands is Crossett's study from Arkansas state with Pinus taeda L. (loblolly pine) and Pinus echinata Mill. (shortleaf pine) in the so-called southern pine area. The experiment started in 1937, when a USDA Forest Services research station established a selective forestry experiment, which has continued to this day. Recently, the effort to integrate the disturbance regime into forestry has been made in America, requiring first and foremost fundamental knowledge of stand age structure (O'Hara, 2002). That is also why a new concept of cultivation of uneven-aged stands is increasingly popular there, attempting to integrate a flexible approach 
to frequency and intensity of management interventions for achieving more variable stand structures, which need not correspond to the traditional negatively exponential distribution of diameters at breast height. The tool for inspecting production durability and stand stock in used in the area is the MASAM (Multiaged Stocking Control Models), based on the relationship of the Leaf Area Index to the stand production and growth (O'Hara \& Valappil, 1999; O’Hara et al., 2001, 2003; O’Hara \& Kollenberg, 2003).

As a consequence of the spreading of ideas of close-to-nature forest management to numerous European countries, in 1989 PRO SILVA EUROPE (Association of European Foresters Practising Management which Follows Natural Processes) was established in Slovenia. In addition to PRO SILVA, which is probably the best known, other associations have been established to promote silviculture on an ecological basis. As mentioned above, the Working Group for the Close to Nature Forestry (Arbeitsgemeinschaft für naturgemässe Waldwirtschaft - ANW) was established in Germany in 1950. England has its Continuous Cover Forestry Group (Continuous Cover Forestry Group 1992); in North America first the New Forestry organisation (Franklin, 1989) was established, followed by Wholistic Forest Use (Hammond, 1991).

\section{DEVELOPMENT OF CLOSE-TO-NATURE SILVICULTURE IN THE CZECH LANDS}

Similarly to Germany and Switzerland, the Czech lands made early attempts at rational forest management corresponding in many aspects to the principles of close-to-nature silviculture. The most prominent advocates of these efforts included Liebich, the first associate professor of forest science at the Czech Technical University in Prague, who pointed out the harmful effects of excessive establishment of forest monocultures already in the first half of the 19th century. The most prominent advocate of the alternative forestry movement towards the end of the19th century was Tichý $(1884,1891)$, who radically refused clear cutting and promoted forest management following laws of nature. According to Tichý, this leaves only individual selection or cluster selection forestry (Poleno 1996).

An important person in the first half of the 20th century was Konšel, who presented and promoted the principles of close to nature forest management in his "Silviculture on a biological basis" (Konšel, 1931).

The first practical implementer of close-to-nature forest management in the Czech lands was Konias, manager of Opočno manor farm. For a period of 30 years after 1924, he continued transforming spruce and pine monocultures into mixed forests and, later, clearing forest types into selective forests (Konias, 1946, 1951, 1952). In the first stage, Konias pursued recovery of forest soil and securing and strengthening of forest stands by way of necessary transformation of species composition towards one that matched the site conditions. In the second stage (in mixed stands), he promoted and created uneven-aged stands by gradually changing the horizontal canopy to a vertical and spatial canopy. The overall result of his efforts in both management directions, Konias expected increased and continuously increasing (to a possible maximum) production, with a special emphasis on improvement and gradation of timber quality (Konias, 1951). Indeed, his work resulted in mixed stands fully corresponding to the site, highly uneven in age, adapted to both natural and management requirements in terms of internal spatial distribution and regeneration period. He paid increased attention to management of stand stock (Poleno, 1996).

Selective forestry gradually became KONIAS' management objective. However, the application of transitions to selective forests across the entire scale of growth conditions of the Opočno county is regarded as a drawback of Konias' work, and it was for these reasons that Konias' idea of "Czech selective forest" has not come true. Only remnants of the large 
quantity of unfinished stands in the Opočno county have survived this day, and those areas have not confirmed successful implementation of his transitions. Findings obtained from assessments of transitions in the individual habitats and stand types (Zakopal, 1959; 1965) can be applied in other management forms, particularly the shelterwood system, which has much broader applicability due to its variability. However, the management implemented by Konias was by no means loss-making; increased quantitative production has not been confirmed, but the qualitative superiority is indubitable (Souček, 2001).

Besides Konias \& Polanský $(1959,1960,1961)$ was a major advocate of selective forestry as a full-fledged management method; he was convinced that selective management methods are not bound to a site or tree species but that a corresponding selective method can, or must be found for each site condition and tree species. That forest would be more productive than an even-aged forest. He wanted to implement these ideas practically in the greater part of the Masarykův Les University Forest Enterprise at Křtiny (MLUFE), regardless of the natural conditions and forest species composition. Selective management methods were in common use after 1951, and forest management plans specifically defined in the period $1963-1972$. However, Polanský's idea did not come true, and after a critical evaluation of this approach in 1972, it was decided that the MLUFE would abandon application of selective principles and prefer shelterwood system (Truhlár, 1996; Souček, 2002b).

Other advocates of selective management were Kratochvíl (1970) and Zakopal (1959; 1965); the latter designed a concept for transforming a even-aged forest to a selective forest in Kutná Hora FMU. Based on this, Šach developed Framework Management Guidelines for the transformation of an even-aged forest to a selective forest in Kutná Hora FMU in the mid 1970s.

Particularly thanks to Konias, shelterwood system became quite widespread in the Czech lands in the post-war period. It was characterised notably by a departure from clear cutting, relatively long regeneration periods, and an effort to achieve natural forest regeneration and gradual transformation of coniferous monocultures into site-appropriate mixed stands (Čížek, Kratochvíl, Peřina, 1959; Peřina, 1960; Fanta, 1961; Čížek \& Stone, 1963; Poleno, 1967, 1996).

The main advantage of this management method is the achievement of natural forest stand regeneration and all the benefits derived from that. The two-storied stand stage is mostly only temporary (for the regeneration period), and this management method is also applicable to trees with greater light demand. Besides these two ecological advantages, there is an expected positive effect of diameter increment of the top-layer trees, which are left to stand for various periods depending on the site-ecological and the species composition.

In the 1970s and 1980s, the Czech Republic's territory saw a significant decrease in the practical implementation of close to nature silvicultural methods in favour of clear-cutting for reasons that have been presented many times over. Only in the last 30 years has there been a renaissance of close-to-nature management ideas and a significant revival of interest among the practical forestry public in gentler cultivation procedures (Košulič, 1997; 2010). An example of such activity in forestry practice is the Klokočná forest district (e.g., Ferkl \& Remeš, 2015). In terms of forestry science, attention has been paid recently to assessment of long-term transformations of coniferous monocultures into structurally richer stands (Truhlář, 1995; Souček, 2002a; Tesař et al., 2004; Remeš, 2006; Remeš \& Kozel, 2006; Remeš et al., 2006, 2007, 2008; Kučeravá et al., 2013; Dobrovolný \& Tesař, 2010; Dobrovolný, 2016). Attention was also paid on objectivisation of selection of individual trees for logging (Poleno, 1999, 2000; Remeš, 2003; Remeš, 2006; Remeš \& Bílek, 2014).

Poleno was involved significantly in close-to-nature forest management issues in the late 1990s. He made a comprehensive analysis of the logging system implemented by selection of 
individual trees in originally even-age forest. According to Poleno (1999), this procedure is more convenient than clear-cutting regeneration, since it enables individual assessment of growth and development stage of each tree for the entire stand development period. Genetic and phenotype variability cause each stand to show more or less variability in attributes and development stages.

\section{CHARACTERISTICS OF CNS}

Close-to-nature silviculture should be highly flexible and essentially should not have very specific management guidelines. As emphasised by Otto (1995), close-to-nature forestry "requires definition of only basic target ideas in the form of target pictures; the cultivation paths themselves remain open and deliberately variable".

Thus, this system does not recognise any complex management models and intricate work procedures. The motto is giving nature maximum chance to make the forest. A part of the professional public see this as a great advantage (advocates), while others see it as a drawback (opportunist approach without a clearly defined and specific target). A common denominator of the close-to-nature aproaches of thought has been an opposition to clear-cutting and management of even-aged monocultures.

The idea of selective forest has played an extraordinary role in the development of closer-to-nature forms of silviculture; it has blended with the history of modern forestry. Since the $19^{\text {th }}$ century, many European forests have felt attracted particularly by the possibility of constantly regeneration forest, sustainability of the forest ecosystem and applicability of the constant forest production and yield principle in every single area of a forest management unit (Poleno, 1996). That is why selective forest has become a model and goal for many foresters (Gurnaud, Bernhardt, Biolley, Ammon, Dannecker, Reininger, Tichý, Konias, Zakopal, Polanský, Korpel', Saniga, Schütz, Kratochvíl, and more). At present, we are again witnessing an extraordinary amount of interest in selective forestry, particularly because the selective management method and its product, the selective forest, is the apex of close-to-nature silviculture for many foresters (Saniga \&Vencurik, 2007).

The common attribute of all the schools of close-to-nature forestry is an effort for maximum diversity of forest stands and rejection of stereotypy and schematisation. The stand diameter (DBH) structure is of great importance for all the main approaches of close-to-nature silviculture, but it is closely linked to the height structure, or vertical distribution of trees. Assessment of structure (diversity) of stands in close-to-nature silviculture most commonly uses DBH frequency distribution and tree species composition (Buongiorno et al., 1994; Lähde et al., 1999). Along with them, the stand spatial structure in the sense of regular or irregular structure of trees in the stand is assessed (Schütz, 1999).

Probably the best-known for close-to-nature silviculture methods is the distribution of frequency of trees in DBH classes characterised by a decreasing geometrical sequence, as defined for selective forests by Liocourt (1898). Calculation of this geometrical sequence requires inference of coefficients $\mathrm{A}$ and q, because the number of trees in each DBH category is determined by the calculation:

$$
N_{n}=A \cdot q^{-(n-1)}
$$

Since $A$ is the frequency of trees in the first DBH class, the frequency of each subsequent $\mathrm{DBH}$ class is determined from that of the previous one by multiplying it with the quotient $\mathrm{q}$. 
Liocourt's work was picked up by Meyer (1931), who expressed tree frequency in the selective forest as a function of the thickness at breast height, a natural exponential function denoted as:

$$
V(x)=y=k e^{-\alpha x}
$$

where

$\mathrm{y}-$ tree frequency

$\mathrm{x}$ - diameter at breast height

$\mathrm{k}, \alpha$-constants characterising the curve type.

As mentioned above, this distribution of thickness frequencies is the model for the diameter structure of selective forest, which are forest stands with maximum age diversity. The principle of greater age differentiation is in fact another attribute that is common to all schools of close-to-nature forest management (e.g., Buongiorno et al., 1994; Lähde et al., 1999; Poleno, 1996; and others).

Model comparisons of the structure of differentiated and undifferentiated forest stands are shown in Figures 1 and 2. The Sibyla growth simulator was used (Fabrika, 2005; Fabrika \& Pretzsch, 2011).

Fig. 1: Model comparison of diameter structure of the even-aged and uneven-aged forest stand

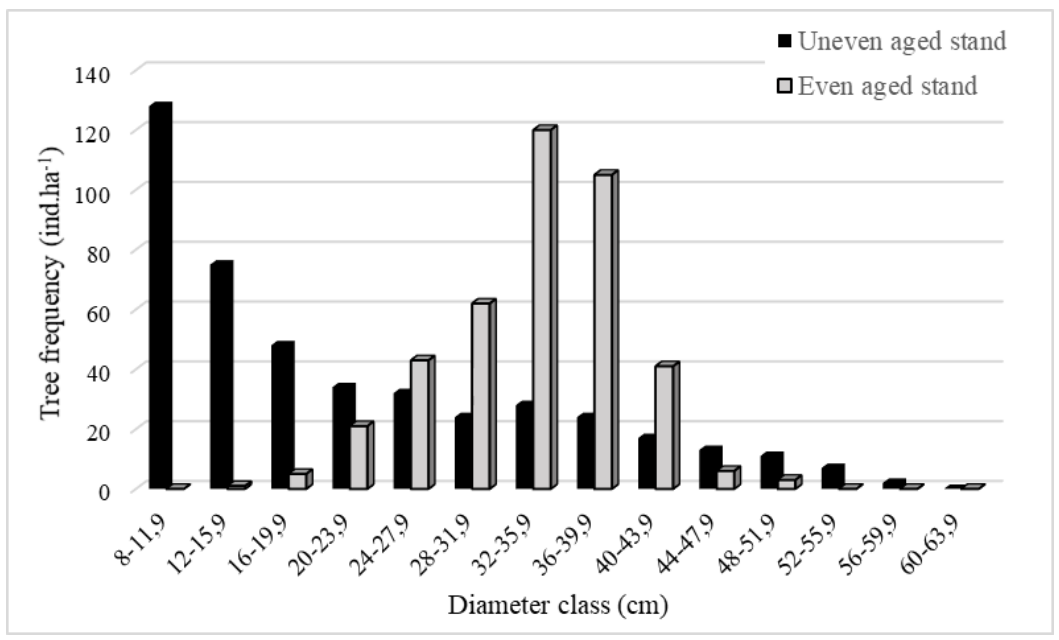


Fig. 2: Model visualization of the vertical and horizontal structure of the even-aged and uneven-aged forest stand
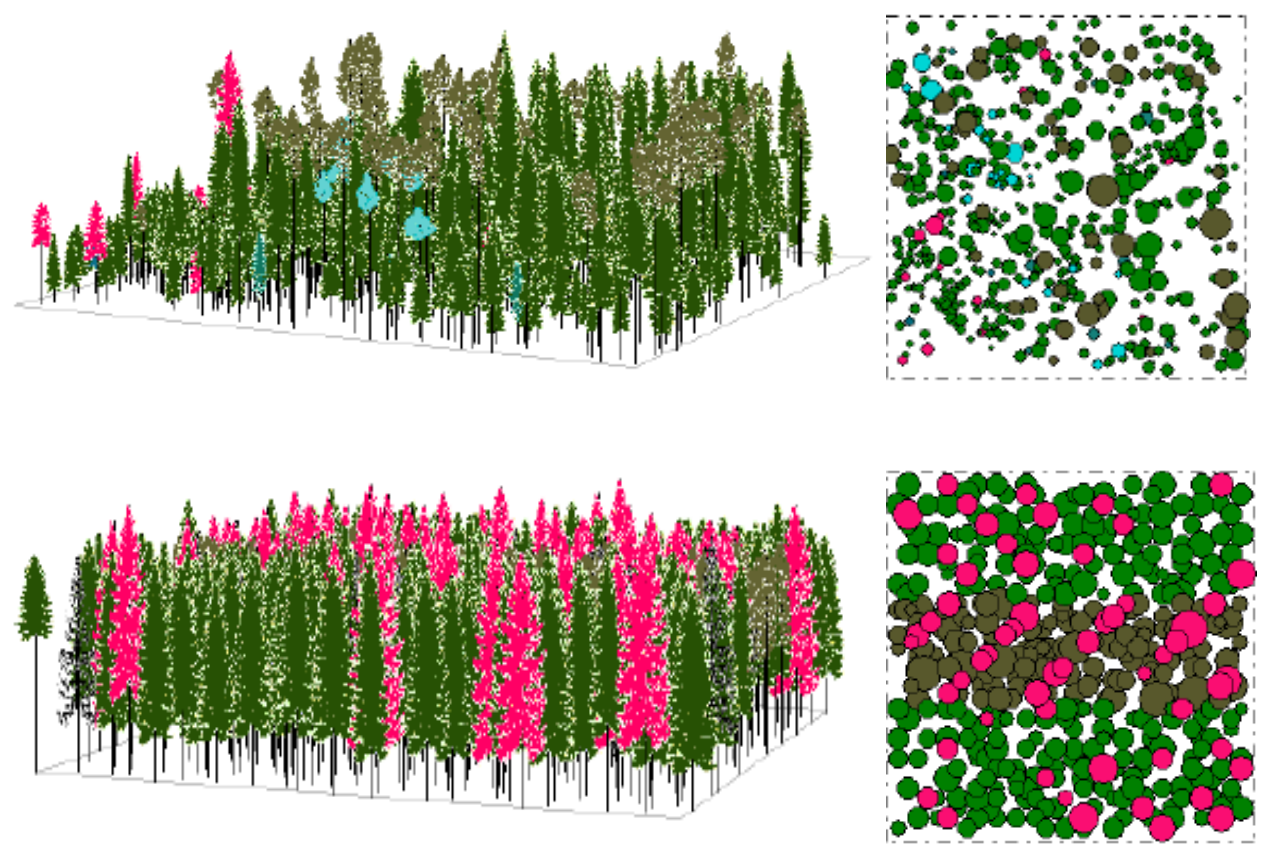

Along with that, another important attribute is an effort for more natural forest stands. That applies notably to the species composition and age differentiation of forest stands as well as maximum effort to exploit natural development processes.

It is evident from the above analysis that there have been numerous approaches to close-to-nature forest management. They differ from each other to various degrees. However, certain common attributes can be found for all of them:

- $\quad$ ecosystem concept of the forest (all components are considered);

- $\quad$ diversification of stand structure:

- species composition closer to natural one;

- spatial horizontal structure mostly irregular, mosaic layout;

- vertical stand structure more complicated, vertical canopy more common than horizontal;

- diameter and height structure more varied;

- $\quad$ maximum utilization of natural forces and processes (differentiation, autoreduction);

- emphasis on natural forest regeneration with relatively long regeneration periods, small-scale regeneration units, up to cutting of individual trees in some types;

- $\quad$ restriction on additional energy inputs to forest ecosystem;

- departure from clear-cutting, continuous vegetation cover of soil (growing of trees in shade);

- $\quad$ increased emphasis on other forest functions, multifunctionality;

- a typical attribute is frequently an opportunistic attitude, with the target adapted to the forest development (can be seen as both an advantage and a drawback); 
- $\quad$ exploitation of individual increment potential of individual trees.

The methods differ from each other mostly in:

- duration of application of selective principles;

- duration of the regeneration period;

- $\quad$ preference of positive or negative selection in stand tending;

- criteria for tree selection for logging.

\section{CURRENT SITUATION AND SOME PROBLEMS ASSOCIATED WITH CNS}

A frequent problem with close-to-nature forest management is its uncritical identification with selective management only, or an effort for maximum differentiation of forest stand structure, defined, as mentioned above, by the sigmoid curve of tree frequencies in DBH classes. That said, it is not automatically true that forest stands with such a distribution frequency of trees in DBH classes are always age-differentiated stands, as pointed out, e.g., by Nyland (1996) and Smith et al. (1997). Differentiation is a natural process resulting from genetic diversity and variable microhabitat conditions. That is why irregularity and differentiation of stand structure is mostly denoted using the term uneven-aged rather than uneven-sized. Differentiation of stand structure can also be understood and assessed at various levels: from heterogeneity in the treetop layer (which can be a major indicator for some fauna species - birds) to full heterogeneity in vertical irregularity at the stand level (selective forest) to horizontal irregularity over larger areas due to irregular shelterwood management. Another structural differentiation is by time. There is temporary stand differentiation versus permanently differentiation (Schütz, 2002).

There is an analogous assumption that the other two basic principles of close-to-nature silviculture, namely age differentiation and greater diversity of tree species, have to be met simultaneously or have to condition one another. However, this assumption may not be in accordance with the natural development processes (disturbances and their effects) or with the requirement for economic effectiveness of the management. Some authors say that achievement and permanent maintenance of a fully diversified stand structure is extremely difficult and, moreover, does not correspond to the results of natural forest succession. Schütz (1999), for example, points out that Switzerland has not managed to meet all the declared goals in spite of more than a century of practical implementation of the close-to-nature forest management concept as formulated by Gayer $(1880 ; 1886)$ in the late 19 th century. First and foremost, the achievement of mixed stands proved to be very difficult, though it was one of the principal goals of Gayer's concept. The principal cause is the fact that tree mixing complicates stand development and mixed stand require more intensive cultivation interventions, which have to ensure survival of less competitive tree species. If such measures are abandoned, the natural stand development tends towards the dominance of a low number of the most competitive tree species, which produce relatively un-mixed stands. This fact has been confirmed by studies of natural forests in Europe, whose developmental ontogeny tends towards a relatively simple stand structure with low tree species diversity, mostly under better habitat conditions. Natural permanently mixed stands in Europe can only be found under impaired habitat and climate conditions, at the interface between the primary tree species zones or outside the natural beech area (Schütz, 1999; Schütz et al., 2016). 
A similar principle has been identified in relation to irregular stand structure. Generally, natural (virgin) forests in Europe incline towards relatively simple stand structure for a significant portion of their developmental cycle (from end of ingrowth stage to end-of-optimum stage); structural homogenisation is the dominant developmental principle. Only in the growing (regeneration) stage, when the stand canopy is more permanently disrupted, is the stand structure irregular. Obviously, stand development significantly depends on site and growth conditions, as documented, e.g., by Korpel' $(1982 ; 1995)$. For these reasons as well, Switzerland has failed to achieve everywhere the second major goal of Gayer's silvicultural concept, irregular stand structure. All that despite the fact that Switzerland is considered the selective forest country. It was there that Biolley defined this management method in the late 19th century. Although selective management has great advantages, consisting in long-term even ability to perform all functions based on biological rationalisation or "natural automation" (making it absolutely unique), the selective forest stand structure is very difficult to achieve and sustain in the long term in practice (Schütz, 1999). For example, experiments with achievement of a selective structure in cases of deciduous stands and stands of light-demanding tree species have failed almost completely. There, the problem with application of individual tree cutting was the lack of natural regeneration, notably for shading of less tolerant species (Schütz, 2002).

Similar reservations to the a priori assumption that natural forests are mostly characterised by their balanced differentiated structure in the climax stage (balanced stands with constant q-factor) have been documented on the American continent. Leak \& Gottsacker (1985) found only very few natural (unmanaged) old stands in which the DBH structure was balanced according to Meyer's curve with a constant q factor. Nevertheless, the typical situation was one where increasing diameter at breast height was coupled with increasing q factor characterising the frequency curve. Goff \& West (1975) stated that the rotary sigmoid curve form better described the distribution of $\mathrm{DBH}$ frequencies in natural old deciduous stands in Wisconsin state. Stands with a pronounced variable structure also form in the case of forest development after disturbances (including even-aged stands); their structure can be very different from that of permanently uneven-aged and structurally different selective stands (Oliver \& Larson, 1996). Thus, from the point of view of naturalness, the effort to transform same-age plantations (monocultures) into stands with a purely selective structure could be seen as counterproductive, because these stands are also unnatural to a great extent (O’Hara, 2002).

At present, the ongoing climate change has inspired the seeking for most appropriate adaptation measures and a debate of how compatible close-to-nature silviculture methods are with the adaptation principles (Bauhus et al., 2013; Brang et al., 2014; Spathelf et al., 2015). That said, it has been stated that the practical implementation method matters a lot. The individually selection system is not the option variant and the cluster selection system or irregular shelterwood system (cluster size of 0.05-0.5 ha) appears the most flexible method in light of adaptation principles. There is potential for further development, particularly using artificial regeneration and specific stand tending. However, some dogmas have to be revised, such as not using introduced tree species and site-introduced populations with a higher adaptation potential. It can also be expected that global changes will lead to new disturbance regimes (depending on habitat and regional conditions), which may fundamentally differ from the historical ones and which cannot be ignored by forest management (O'Hara, 2016). That said, the expectation is for increasing frequency, intensity and extent of disturbance of forest ecosystems due to both abiotic and biotic factors. It is observable at present already. In this connection, the scientific community has polemicized whether historically defined principles of close-to-nature forest management correspond to present and future dynamics 
of natural forest development, thus how close-to-nature forest management is actually close to nature (Schütz et al., 2016; O'Hara, 2016). One side of the debate (voiced mostly by North America) argues that the former concept of close-to-nature silviculture aimed at increasing stand stability, ensuring constancy and stability of production on minimum required land (which in practice meant minimising the effect of disturbances). Contrary to that, the (new) concept based on exploitation of natural disturbances as a model for silvicultural measures may become more contradictory to principles such those defined by Pro Silva organisation (O'Hara \& Nagel, 2013; O'Hara, 2016). On the other hand, analyses of development of structure, life cycle duration and temporal and spatial dynamics of regeneration of the best-preserved virgin forests in the temperate zone of Europe are used to document the validity of the original principles of close-to-nature management. It must be noted that these include not only selective methods but also irregular shelterwood (Femelschlag system), where regeneration takes place by clusters. Successful regeneration of light-demanding tree species assumes the min. size of 0.25 ha in the regeneration phase and min. 0.5 ha in the pole stage (Schütz, 1992).

\section{CONCLUSION}

For the above reasons and based on long-term experience and failures of the effort to practically implement selective management, close-to-nature silviculture has to be understood more widely than is often the case today. After all, it happened in the first half of the $20^{\text {th }}$ century already, when Schädelin (1928) and Leibundgut (1946) included both selective forest (selection system) and irregular shelterwood method in the close-to-nature silviculture system.

The essential fact is that the close-to-nature silviculture system includes all the methods of regeneration that exist in natural forests. Thus, it must not be an application of individual tree selection followed by individual regeneration, forming a highly complex stand structure. The system has to involve more extensive forest regeneration forms performed by larger clusters, to create corresponding conditions for the growth and adequate quality of developing light-demanding tree species (Schütz, 1999; Schütz et al., 2016). Shelterwood system (producing small-scale even-aged stands) may lead to higher biodiversity at the regional level and the landscape level than if uneven-aged stands are cultivated consistently (Schall et al., 2017). That is why the stand structure should be deliberately variable. Likewise, future silviculture has to be variable and highly flexible (O'Hara, 2016). Therefore, the selective management method remains one of the possible, albeit relatively difficult to achieve, alternatives that provides optimum economic and production results in forest stands of shade tolerant coniferous tree species (mostly Norway spruce and European silver fir in Europe Korpel' \& Saniga, 1993).

\section{REFERENCES}

Bauhus, J., Puettmann, K.J., Kühne, C. (2013). Close-to-nature management in Europe. Compatible with managing forests as complex adaptive forest ecosystems? In: Messier C, Puettmann KJ, Coates KD (eds) Managing forests as complex adaptive systems: building resilience to the challenge of global change (pp. 337-354). Routledge, The Earthscan forest library.

Bonan, G.B., Shugart, H.H. (1989). Environmental factors and ecological processes in boreal forest. Ann. Rev. Ecol. Syst. 20: 1-28. 
Buongiorno, J., Dahr, S., Lu, H.-C., Liu, C.-R. (1994): Tree size diversity and economic returns in uneven-aged forest stands. For. Sci. 40(1): 83-103.

Brang, P., Spathelf, P., Larsen, J. B., Bauhus, J., Bončina, A., Chauvin, C., Drössler, L., Garcia-Güemes, C., Heiri, C., Kerr, G., Lexer, M. J., Mason, B., Mohren, F., Mühlethaler, U., Nocentini, S., Svoboda, M. (2014). Suitability of close-to-nature silviculture for adapting temperate European forests to climate change. Forestry 2014, 0, 1-12.

Čížek, J., Kratochvíl, F., Peřina, V. (1960): Přeměny monokultur. SZN Praha, 188 s.

Čížek, J., Stone, B. (1963). Př́íspěvek k teoretickým základům podrostního hospodářství. Sbor. LF VŠZ Praha: 135-155.

Dobrovolný, L., Tesař, V. (2010): Extent and distribution of beech (Fagus sylvatica L.) regeneration by adult trees individually dispersed over a spruce monoculture. Journal of Forest Science, 56(12):589-599.

Dobrovolný, L. (2016): Density and spatial distribution of beech (Fagus sylvatica L.) regeneration in Norway spruce (Picea abies (L.) Karsten) stands in the central part of the Czech Republic. IForest-Biogeosciences and Forestry, 9: 666-672.

Fabrika, M. (2005). Simulátor biodynamiky lesa SIBYLA, koncepcia, konštrukcia a programové riešenie. Habilitačná práca. Zvolen, Technická univerzita vo Zvolene, $238 \mathrm{~s}$.

Fabrika, M., Pretzsch, H. (2011). Analýza a modelovanie lesných ekosystémov. Zvolen, Technická univerzita vo Zvolene. $599 \mathrm{~s}$.

Ferkl, V., Remeš, J. (2015). Klokočná čtvrt století poznatků, zkušeností a výsledků z nepasečného hospodaření založeného na zpưsobu výběrných těžeb. ČZU v Praze, $38 \mathrm{~s}$.

Franklin, J.F., 1989: Towards a new forestry. Am. For. 95 (11/12): 37-44.

Frivold, L.H. (1992). Ecologically oriented silviculture in the boreal coniferous forest zone. IUFRO, Proc. Centennial, Berlin-Eberswalde, Germany, 31 August-4 September 1992, 215 s.

Fanta, J. (1961): Uplatnění př́růstového hospodářství při obnově smrkových porostů. Práce výzkumného ústavu les. ČSSR, 21: 6-30.

Gayer, K. (1880). Der Waldbau. Wiegandt\&Hempel\&Parey, Berlin, 700 s.

Gayer, K. (1886). Der gemischte Wald, seine Bergründung und Pflege, insbesondere durch Horst-und Gruppenwirtschaft. Berlin, Parey, 168 s.

Goff, F.G., West, D. (1975). Canopy-understory interaction effects on forest population structure. For. Sci. 21:8-108.

Hammond, H. (1991). Seeing the Forest Among the Trees. The case for Wholistic Forest Use. Polestar Press. Vancouver, 309 s.

Haveraaen, O. (1995). Silvicultural system in the Nordic countries. In: Bamsey, C.R. (Ed.), Innovative Silvicultural Systems in Boreal Forests (p.1-4.). Proc. IUFRO Symposium in Edmonton, Alberta, Canada, 2-8 October 1984, Natural Resources Canada, Canadian Forest Service.

Heger, A. (1930). Vorratswirtschaft im oberen Erzgebirge. Sudetendeutsche Forst- u. Jagdzeitung, 30: 258-264.

Heger, A. (1953). Die Sicherung des Fichtewaldes gegen Sturmschäden. 2. Aufl., Radebeul u. Berlin. Český překlad: Ochrana smrčin proti škodám větrem. Praha, 1957.

Heger, A., Schönbach H. (1955): Lehrbuch der forstlichen Vorratspflege. Neumann Verlag, Radebeul - Berlin, 1955. Slovenský překlad: Bezačinský H.-Červenka E., 1962: Pestovanie 
zásoby lesného stromovia. SVPL Bratislava, 207 s.

Hytteborn, H., Liu, Quinghong, Verwjist, T. (1991). Natural disturbance and gap dynamics in a Swedish boreal spruce forest. In: Nakagoshi, N., Golley, F.B. (Eds), Coniferous Forest Ecology from International perspective (pp. 93-108). SPB Academic Publishing, The Hague.

Koch, N.E., Skovsgaard, J. P. (1999): Sustainable management of planted forests: some comparisons between central Europe and the United States. New. For. 17: 11-22.

Konias, H. (1946). Převody opočenských lesů. Praha.

Konias, H. (1951). Lesni hospodářství. Praha.

Konias, H. (1952). Jak postupovat při přeměnách nesmíšených porostů ve smíšené a př̀evodů pasečných tvarů na výběrné. Lesnická práce, 31

Konšel, J. (1931). Stručný nástin tvorby a pěstěni lesů v biologickém ponětí. Praha: Matice lesnická, $552 \mathrm{~s}$.

Korpel', $\breve{S}$. (1982). Degree of equilibrium and dynamical changes of the forest on example of natural forests of Slovakia. Acta Fac. For. Zvolen. 24: 9-31.

Korpel', Š. (1995). Die Urwälder der Westkarpaten. Fischer, Stuttgart\&Jena, New York, 310 s.

Korpel', Š., Saniga, M. (1993). Výberný hospodárský spôsob. VŠZ - lesnická fakulta Praha Matice lesnická Písek, 127 s.

Kučeravá, B., Dobrovolný, L., Remeš, J. (2013). Responses of Abies alba seedlings to different site conditions in Picea abies plantations. Dendrobiology, 69: 49-58.

Košulič, M. (1997). Těžba cílových tlouštěk aneb směr k ekologickému lesu. Lesnická práce, 76 (8): 292-293.

Košulič, M. (2000). Cesta k prírodě blizkému hospodářskému lesu. FSC ČR, o.s. $449 \mathrm{~s}$.

Kratochvíl, F. (1970). Výsledky hospodaření v kutnohorských lesích. Lesnická práce, 49 (6): 277-279s.

Krutzsch, H., Weck, J. (1934). Bärethoren 1934. Der naturgemässe Wirtschaftswald. Neudamm.

Lähde, E., Laiho, O., Norokorpi, Y. (1999). Diversity oriented silviculture in the Boreal Zone of Europe. For. Ecol. Manag. 118: 223-243.

Leak, W.B., Gottsacker, J.H. (1985). New approaches to uneven-aged management in New England. North. J. Appl. For. 2: 28-31.

Leibundgut, H. (1946). Femelschlag und Plenterung. Beitrag zur Festlegung waldbaulicher Begriffe. Schweiz. Zeitschrift für Forstwesen, 97: 306-317.

Meyer, W.H. (1931). Eine mathematisch-statistische Untersuchung über den Aufbau des Plenterwaldes. Schweiz. Zeitschrift für Forstwesen, 84: 33-46, 88-103.

Mlinšek, D. (1996). From clear-cutting to close-to-nature silviculture system. International Union of Research Organization, IUFRO News 25 (4): 6-8.

Möller, A. (1921). Dauerwaldwirtschaft. Berlin, Springer, 54 s.

Möller, A. (1922). Der Dauerwaldgedanke. Sein Sinn und seine Bedeutung. Berlin, Springer, $84 \mathrm{~s}$.

Nyland, R.D. (1996): Silviculture: Concepts and Application. McGraw-Hill, New York.

O'Hara, K.L., Valappil, N.I. (1999). MASAM - a flexible stand density management model for meeting diverse structural objectives in multiaged stands. For. Ecol. Manag. 
$118(1-3) 57-71$.

O’Hara, K.L., Lähde, E., Laiho, O., Norokorpi, Y., Saksa, T. (2001). Leaf area allocation as a guide in stocking control in multiaged, mixed conifer forests in southern Finland. Forestry 74(2): 171-185.

O'Hara, K.L. (2002). The historical development of uneven-aged silviculture in North America. Forestry, 75 (4): 339-346.

O'Hara, K.L., Kollenberg, C.L. (2003). Stocking control procedures for multiaged lodgepole pine stands in the northern Rocky Mountains. Western Journal of Applied Forestry 18(1): 15-21.

O’Hara, K.L., Valappil, N.I., Nagel, L.M. (2003): Stocking control procedures for multiaged ponderosa pine stands in the Inland Northwest. Western Journal of Applied Forestry 18(1): 5-14.

O'Hara, K.L., Nagel, L.M. (2013): The stand: revisiting a central concept in forestry.J.For.111, 335-340.

O'Hara K.L. (2014): Multiaged Silviculture: Managing for Complex Forest Stand Strucutre. Oxford University Press, $213 \mathrm{pp}$.

O’Hara K.L. (2016): What is close-to-nature silviculture in a changing world? Forestry. 89: 1-6.

Oliver, C.D., Larson, B.C. (1996). Forest Stand Dynamics. John Wiley \& Sons, Inc., New York.

Otto, H. J. (1995): Zielorientierter Waldbau und Schutz sukzessionaler Prozesse. Forst u. Holz, 50: 203-209.

Peřina, V. (1960). Přeměny borových monokultur na pleistocenních terasách. VÚHLM, ČSAZ, SZN Praha, $210 \mathrm{~s}$.

Polanský, B. (1959). Studie u nás vytvořených tvarů výběrného lesa. Lesnictví, 5: 995-1012.

Polanský, B. (1960): Náměty na zpřesnění pojmu výběrné hospodářství a jeho principů. Lesnictví, 6: 255-258.

Polanský, B. (1961): Úprava pasečných způsobů pro možnost uplatnění principů výběrného hospodářství. Lesnictví, 7: 339-368

Poleno, Z., 1967: Podrostni hospodářství jako jedna z cest zvyšováni produkce lesa. Kandidátská disertační práce, Praha, 236 s.

Poleno, Z. (1993). Ekologicky orientované pěstování lesů I. Lesnictví-Forestry, 39(11): 475-480.

Poleno, Z. (1994). Ekologicky orientované pěstování lesů II. Lesnictví-Forestry, 40(1-2): 65-72.

Poleno, Z. (1996). Přrirodě blizké lesní hospodářství. Expertiza pro Lesy ČR, ředitelství Hradec Králové, 52 s. (nepublikováno).

Poleno, Z. (2001). Obhospodařování porostní zásoby či péče o porostní zásobu. In: Odkaz opočenského lesního hospodářství Huga Koniase (s. 53-62), Sborník referátů z celostátního semináře, Opočno 17.5.-18.5. 2001: 53-62.

Remeš, J. (2003). Analýza podrostního způsobu obnovy porostu s uplatněním přiruostového kritéria mýtní zralosti, disertační práce LF ČZU Praha, 291s.

Remeš, J. (2006). Transformation of even-aged spruce stands at the School Forest Enterprise Kostelec nad Černými lesy: Structure and final cutting of mature stand. Journal of Forest 
Science, 2006, 52(4): 158-171.

Remeš, J., Kozel, J., Péris, T.P. (2006). Transformation of a coniferous even-aged forest at the Klokočná forest range. Paper in Proceedings: Welche Bestandesstruktur für welche Waldfunktion. Gemeinsames Waldbau-Kolloquium "Brno - Tharandt", 4.-6.10. 2005 Kutná Hora: 125-133.

Remeš, J., Kozel, J., Podrázský, V. (2007). Přestavba lesa na lesnickém úseku Klokočná. In: Management of forests in changing environmental conditions $(276-282)$. Zvolen 4. - 5. 9.2007. Zvolen, TU Zvolen.

Remeš, J., Kušta, T., Zehnálek, P. (2008). Struktura a vývoj dlouhodobě cloněných nárostů v systému prrírodě blízkého hospodaření v lesích. Zprávy lesnického výzkumu. 54: 41-4

Remeš, J, Kozel, J. (2006). Structure, growth and increment of the stands in the course of stand transformation in the Klokočná Forest Range, Journal of Forest Science, 52(12): 537-546.

Rubner, K. (1931). Vorrauspflege im Rahmen der Betriebsarten. Allg. Forst- u. Jagdztg., 102:7: 117-122.

Rubner, K. (1936). Die Waldbautechnik der grössten Wertleistung. Neumann, Neudamm-Berlin, $126 \mathrm{~s}$.

Saniga, M., Vencurik, J. (2007). Dynamika štruktúry a regeneračné procesy lesov v rôznej fáze prebudovy na výberkový les v LHC Korytnica. TU Zvolen, Lesnícka fakulta $83 \mathrm{~s}$.

Schädelin, W. (1928). Stand und Ziele des Waldbaues in der Sweiz. Schweiz. Zeitschrift für Forstwesen. 79: 119-139.

Schall, P., Gossner, M.M., Heinrichs, S., et al. (2017). The impact of even-aged and uneven-aged forest management on regional biodiversity of multiple taxa in European beech forests. Journal of Applied Ecology. 2017; 00:1-12.

Schütz, J.P. (1992). Die waldbaulichen Formen und die Grenzen der Plenterung mit Laubbaumarten. Schweiz. Zeitschrift für Forstwesen 143:442-460.

Schütz, J.P. (1999). Close-to-nature silviculture: is this concept compatible with species diversity? Forestry, 72(4): 359-366.

Schütz, J.P. (2002). Silvicultural tools to develop irregular and diverse forest structures. Forestry, 75(4): 329-337.

Schütz, J.P., Saniga, M., Diaci, J., Vrška, T. (2016). Comparison close-to-nature silviculture with processes in pristine forests; lessons from Central Europe. Annals of Forest Sciences, 73: 911-921.

Smith, D.M., Larson, B.C., Kelty, M.J., Ashton, P.M.S. (1997): The Practice of Silviculture: Applied Forest Ecology, 9th Edition. Wiley, New York.

Souček, J. (2001). Výsledek převodů na výběrný les započatých H. Koniasem. In: Odkaz opočenského lesního hospodárství Huga Koniase (s. 18-25), Sborník referátů z celostátního semináře, Opočno 17.5.-18.5. 2001: 18-25.

Souček, J. (2002a). Převod lesa pasečného na les výběrný na př́ikladu výzkumné plochy Opuky. Journal of Forest Science, 48 (1): 1-7.

Souček, J. (2002b). Převod lesa pasečného na les výběrný na př́kladu výzkumné plochy Opuky. Doktorská disertační práce, MZLU FLD Brno,134 s.

Spathelf, P., Bolte, A., Maaten, E. (2015). Is Close-to-Nature Silviculture (CNS) an adequate concept to adapt forests to climate change? Appl Agric Forestry Res. (65)161-170. 
Steijlen, I., Zacrisson, O. (1986). Long-term regeneration dynamics and successional trends in a northern Swedish coniferous forest stand. Can. J. Bot. 65: 839-848.

Tesař, V., Klimo, E., Kraus, M., Souček, J. (2004). Dlouhodobá přestavba jehličnatého lesa na Hetlíně - kutnohorské hospodářství. MZLU v Brně, $60 \mathrm{~s}$.

Tichý, A. (1884). Forsteinrichtung in Eigenregie des auf eine möglichst naturgesetzliche Waldbehandlung bedachten Wirtschafters. Berlin.

Tichý, A. (1891). Der qualifizierte Plenterbetrieb als nachfolgende Entwicklungsstufe einer zuerst im Jahre 1884 veröffentlichten Forsteinrichtungsmethode. München.

Truhláŕ, J. (1995). Results of Conversions to the Selection Forest in the Masarykův les Training Forest Enterprise. Lesnictvi-Forestry, 41 (3): 97-107.

Truhlář, J. (1996). Pěstování lesů v biologickém pojetí. ŠLP Křtiny, 128 s.

Zakopal, V. (1959). Studie u nás vytvořených tvarů výběrného lesa. Lesnictví: 995-1012.

Zakopal, V. (1965). Zhodnocení vývoje převodů pasečných tvarů na výběrné na Opočensku. Práce VÚLHM, Jíloviště-Strnady, 30: 225-271. 